\title{
Conservation of genes encoding components of a type IV pilus assembly/two-step protein export pathway in Neisseria gonorrhoeae
}

\author{
Peter Lauer, ${ }^{\dagger}$ Nan H. Albertson ${ }^{\ddagger}$ and \\ Michael Koomey* \\ Department of Microbiology and Immunology, \\ University of Michigan Medical School, Ann Arbor, \\ Michigan 48109-0620, USA.
}

\section{Summary}

Three gonococcal genes have been identified which encode proteins with substantial similarities to known components of the type IV pilus biogenesis pathway in Pseudomonas aeruginosa. Two of the genes were identified based on their hybridization with a DNA probe derived from the pilB gene of $\boldsymbol{P}$. aeruginosa under conditions of reduced stringency. The product of the gonococcal pilF gene is most closely related to the pilus assembly protein PilB of $P$. aeruginosa while the product of the gonococcal pilT gene is most similar to the PilT protein of $P$. aeruginosa which is involved in pilus-associated twitching motility and colony morphology. The products of both of these genes display canonical nucleoside triphosphate binding sites and are predicted to be to cytoplasmically localized based on their overall hydrophilicity. The gonococcal pilD gene, identified by virtue of its linkage to the pilF gene, is homologous to a family of prepilin leader peptidase genes. When expressed in Escherichia coli, the gonococcal PiID protein functions to process gonococcal prepilin in a manner consistent with its being gonococcal prepilin peptidase. These results suggest that Neisseria gonorrhoeae is capable of expressing many of the essential elements of a highly conserved protein translocation system and that these gene products are probably involved in pilus biogenesis.

\section{Introduction}

Filamentous proteinaceous appendages termed pili

Received 29 September, 1992; revised 30 November, 1992; accepted 15 December, 1992. Present addresses: †Department of Molecular and Cell Biology, University of California, Berkeley, California 94720, USA; fDepartment of General and Marine Microbiology. University of Göteborg, Göteborg S413 19, Sweden. *For correspondence. Tel. (313) 9360847 ; Fax (313) 7643562 . appear to play a critical role in the ability of Neisseria gonorrhoeae to colonize the human host. The nature of the relationships between gonococcal pili, colonization and disease is not well established but results from many studies support the notion that pili facilitate adherence of the bacterium to the mucosal surface (Heckels, 1989; Swanson and Koomey, 1989). Pilus filaments represent an ordered array of polymerized protein subunits termed pilin and, to date, this polypeptide is the only recognized integral component of the organelle. The short leader sequence and proximal 30 amino acids of gonococcal prepilin show a high degree of homology with prepilins of other Gram-negative organisms including Neisseria meningitidis (Potts and Saunders, 1988), Moraxella species (Marrs et al., 1985; Tønjum et al., 1991), Dichelobacter nodosus (Elleman and Hoyne, 1984), Pseudomonas aeruginosa (Strom and Lory, 1986), Vibrio cholerae (Shaw and Taylor, 1990) and the pilin of certain strains of enteropathogenic Escherichia coli (Giron et al., 1991).

Pili or fimbriae are expressed by many Gram-negative pathogens and commensal bacteria and in all cases the biogenesis of these macromolecular structures requires the co-ordinated action of many gene products (Hultgren and Normark, 1991). In most pilus systems that have been examined, the genes encoding these accessory products are closely linked to the gene encoding the major subunit. While this holds true for the type IV pilus system of $P$. aeruginosa (Nunn et al., 1990) and the related pilus of $V$. cholerae (Taylor et al., 1988) it does not appear to be the case in $N$. gonorrhoeae. Two genes, pilA and pilB, map adjacent to the expression site for the gonococcal pilin subunit but their products appear to exert influence over pilus expression at the level of pilin gene transcription rather than at the levels of transport, processing or assembly (Taha et al., 1988).

Studies of spontaneously arising pilin mutants, as well as those created by site-specific mutagenesis and allelic replacement, have led to the identification of specific amino acid residues and domains of pilin which are required for pilus biogenesis (Koomey et al., 1987; 1991; Zhang et al., 1992). Attempts to isolate and characterize other classes of pilus assembly mutants in gonococci have been confounded by the fact that mutations within the pilin subunit occur frequently as a consequence of the 
recombination process responsible for antigenic variation (Koomey et al., 1987). In recombination-deficient strains, pilin mutations still account for a majority of non-piliated mutants and even for those mutants that do not have mutations in the pilin gene, identification of the altered gene is hampered by the lack of efficient methodologies for complementation studies. Despite these difficulties, a $110 \mathrm{kDa}$ protein, PilC, that copurifies with the gonococcal pilin subunit and its corresponding gene were recently identified. Gonococcal mutants failing to express PilC were reported to express few, if any, pili (Jonsson et al., 1991).

Evidence accumulating from many prokaryotic systems has revealed that components required for the two-step (signal-sequence-dependent) translocation of proteins to the cell surface are structurally and functionally related to proteins involved in type IV pilus biogenesis (Whitchurch et al., 1991; Lory, 1992; Pugsley, 1992). At least three distinct families of genes and corresponding proteins which share significant sequence identity across diverse species boundaries have been proposed to be part of similar apparatuses of extracellular protein localization. These include genes encoding type IV prepilin-like polypeptides, peptidases responsible for amino-terminal processing of the prepilin homologues and cytoplasmic proteins sharing highly conserved nucleoside triphosphate binding sites. Proteins corresponding to one or more of these families have been implicated in the extracellular localization of toxins and hydrolases by many pathogenic Gram-negative bacteria (Dums et al., 1991; He et al., 1991; Strom et al., 1991; Bally et al., 1992; Jiang and Howard, 1992; Sandkvist et al., 1993) and membrane translocation of DNA in Bacillus subtilis (Albano et al., 1989; Mohan et al., 1989) and Agrobacterium tumefaciens (Ward et al., 1988). Further evidence of the relatedness of these pathways can be found in the ability of elements from one system to functionally modify or process substrates from heterologous sources. For example, the prepilin leader peptidase $\mathrm{PilD} / \mathrm{XcpA}$ of $P$. aeruginosa is able to cleave gonococcal prepilin correctly (Nunn and Lory, 1991) and the same activity has been associated with the PulO protein of Klebsiella oxytoca and ComC protein of B. subtilis (Dupuy et al., 1992). Complemention studies have shown that the $x c p$ gene cluster of $P$. aeruginosa can restore protein secretion to a Xanthomonas campestris mutant (deGroot et al., 1991) and that the defect in elastase secretion displayed by XcpA mutants of $P$. aeruginosa can be rectified by expression of the pulO gene of $K$. oxytoca (Bally et al., 1992). Based on these observations, we reasoned that $N$. gonorrhoeae was likely to possess one or more members of these conserved gene families.

In this work, we describe experiments designed to identify gonococcal genes sharing significant sequence homology with the pilus assembly gene pilB of $P$. aeruginosa. These studies resulted in the isolation and characterization of two unlinked gonococcal genes, one of which is a homologue of a broadly disseminated gene family encoding secretion components with canonical nucleoside triphosphate binding domains and another which corresponds to the pilT gene of $P$. aeruginosa, involved in pseudomonas pilus retraction and twitching motility. A third gene, identified by virtue of its linkage with the pilB gene homologue, is a member of the prepilin leader peptidase gene family. We also show that this gene encodes a protein associated with gonococcal prepilin peptidase activity.

\section{Results}

Isolation of two gonococcal chromosomal loci hybridizing with a P. aeruginosa pilB gene probe

The $1.5 \mathrm{~kb}$ Pst I DNA fragment encoding amino acids 27-517 of the PilB protein of $P$. aeruginosa (Nunn et al., 1990) was employed as a radiolabelled DNA probe against restriction digests of gonococcal chromosomal DNA. Using parameters that favoured detection of related but divergent sequences, the probe annealed to multiple DNA fragments. By increasing the stringency of the reaction, conditions were established under which a limited number of fragments retained strong reactivity although weaker hybridizing species could still be detected. The pilB DNA probe was then used under these empirically defined conditions to screen a library of gonococcal genomic DNA cloned in the lambda replacement vector EMBL-3. Individual reactive phage plaques displayed varying intensities of hybridization signal which were consistently maintained on plaque purification and rescreening. The insert DNAs of those clones which gave the strongest hybridization signals were isolated and used as DNA probes against Southern blots of gonococcal DNA. Based on the hybridization patterns and restriction mapping, these phage clones were found to consist of two distinct populations that carried non-overlapping, unique segments of the gonococcal genome and were designated as locus 1 and locus 2 clones.

\section{Sequence analysis of loci 1 and 2}

To define the nature of the homology between the $P$. aeruginosa pilB gene and the cloned gonococcal DNA, hybridizing restriction fragments from representative phage clones were subcloned onto plasmids and the nucleotide sequences determined. Figure 1 shows the DNA sequence of the region of locus 1 clones that includes the pilB DNA homology as well as flanking sequences. Computer analysis showed that this locus 


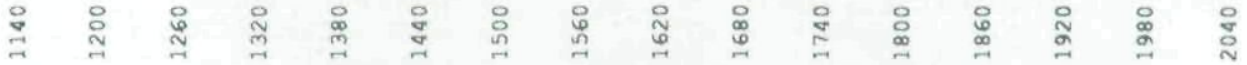

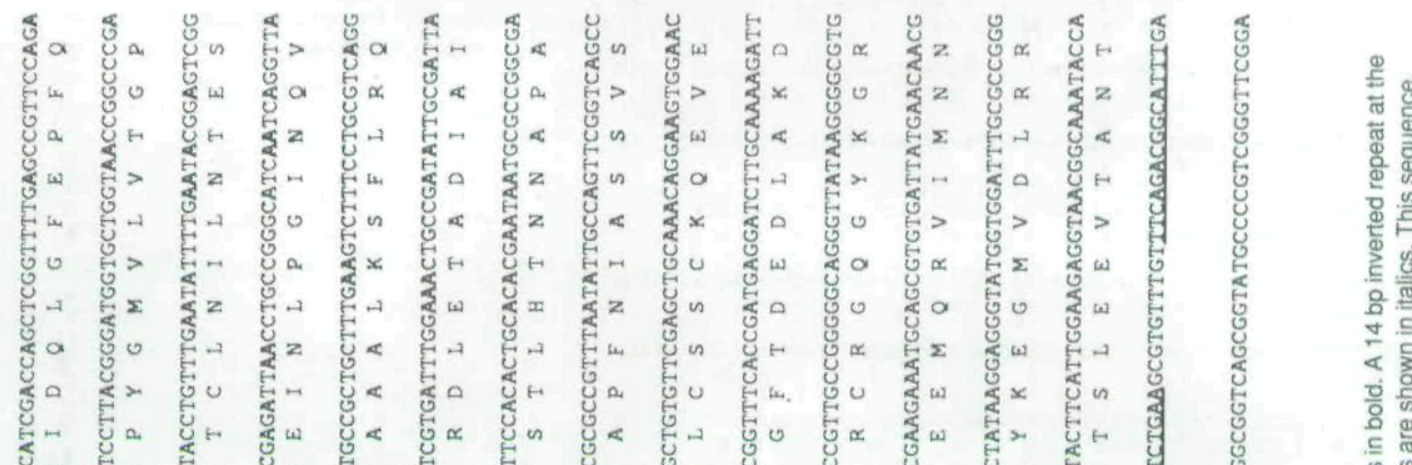

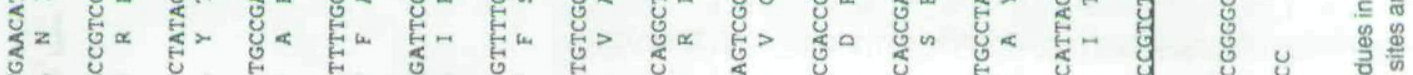

热

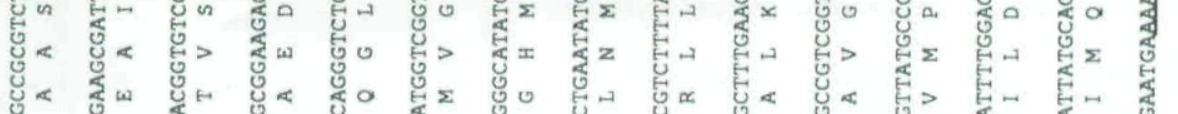

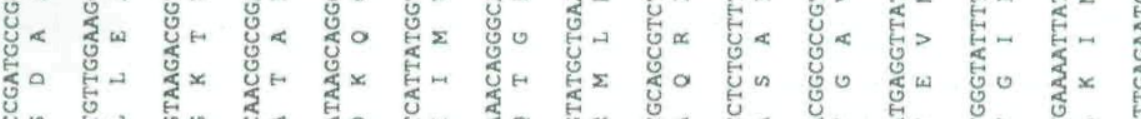

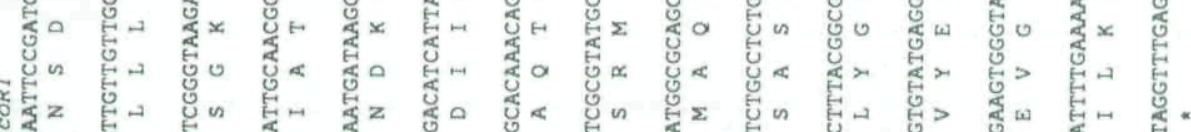

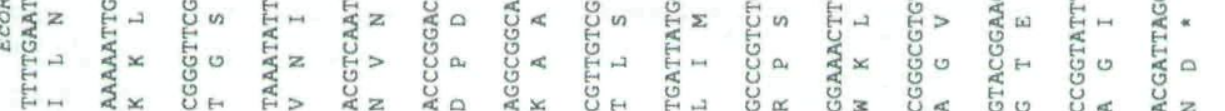

En $\begin{aligned} & \sum_{x} \\ & \overrightarrow{0}\end{aligned}$

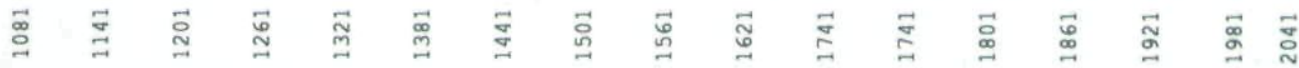

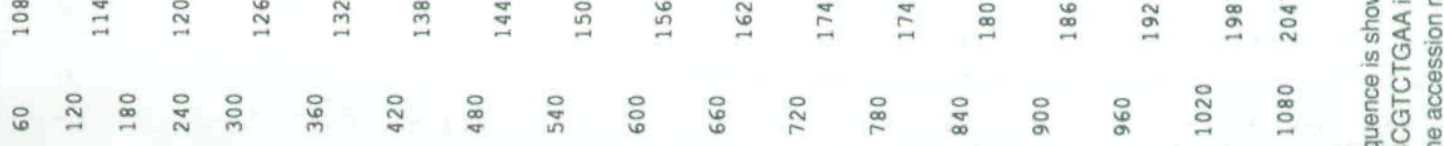

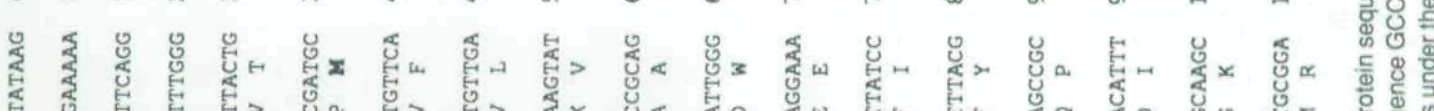

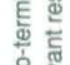

हᄐ

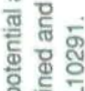

兵弯要通

负 $\underline{\underline{c}}$

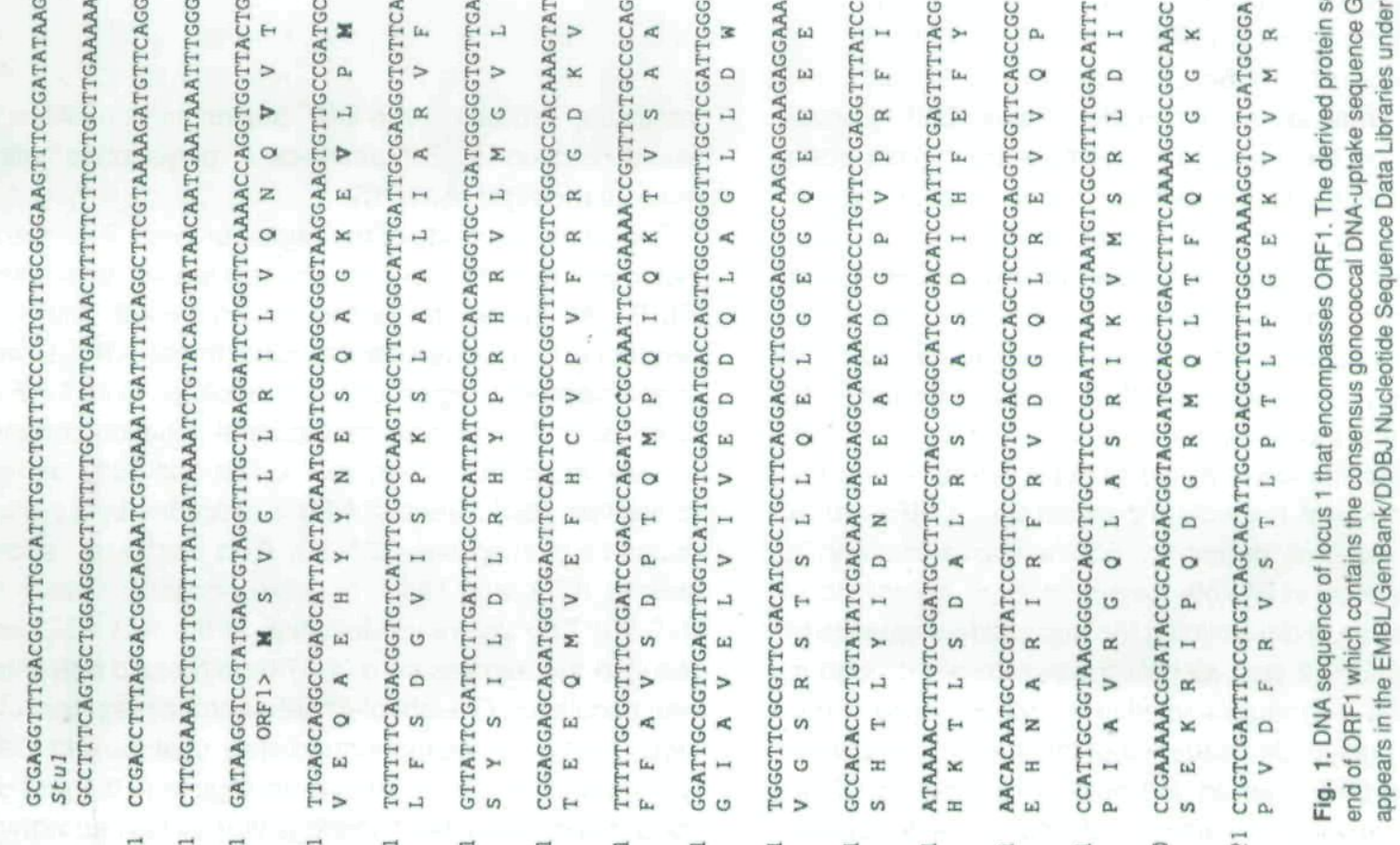

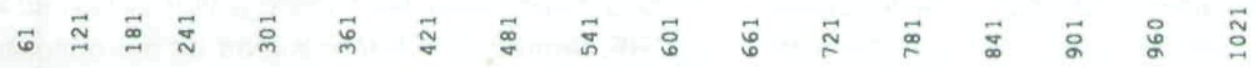




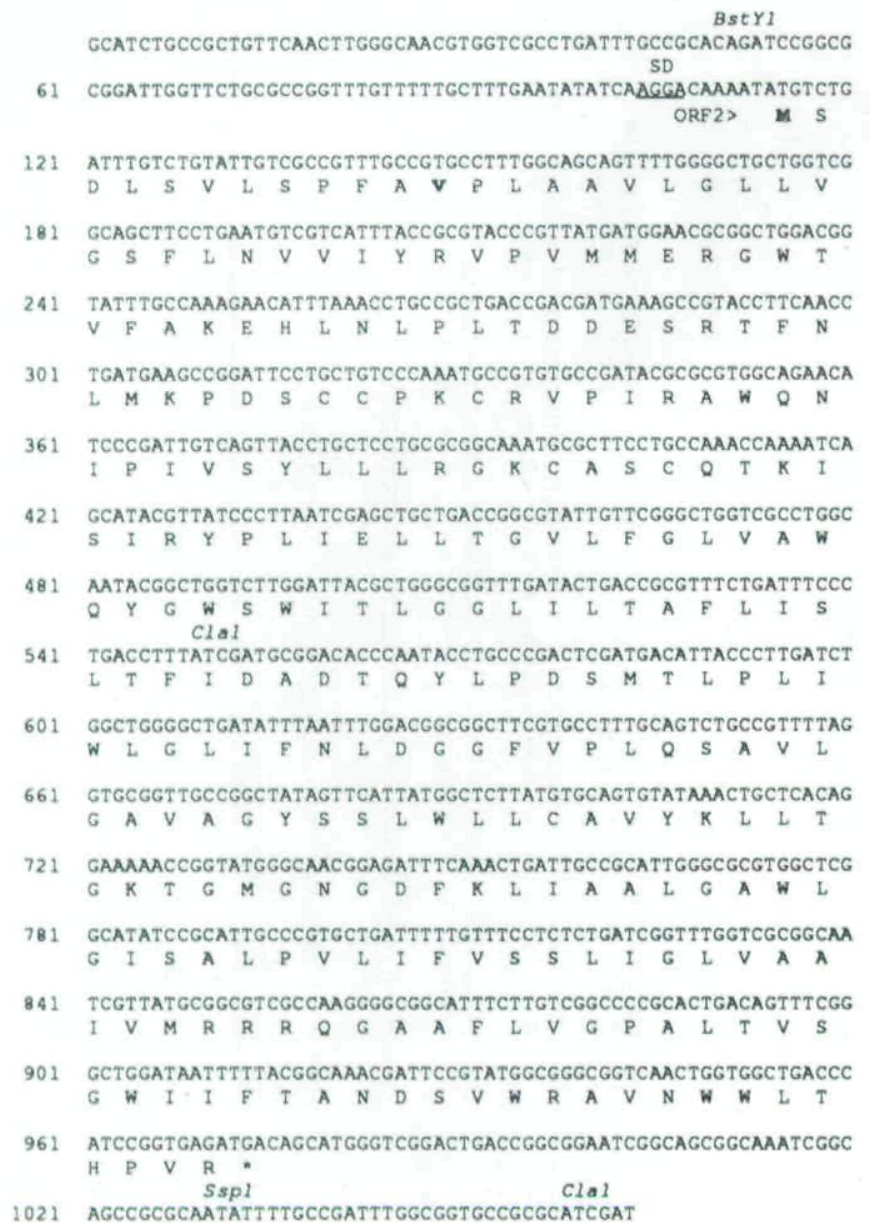

Fig. 2. DNA sequence of locus 1 that contains ORF2. The derived protein sequence is shown with potential amino-terminal residues in bold. A putative Shine-Dalgarno (SD) sequence is underlined and relevant restriction sites are shown in italics. This sequence appears in the EMBL/ GenBank/DDBJ Nucleotide Sequence Data Libraries under the accession number L11715. contains a single large open reading frame (ORF1) which encompasses the region of pilB homology. This open reading frame has four potential in-frame initiation codons at positions 252, 291 (GTG), 348 (GTG), and 357 and ends at position 1926. Just downstream of ORF1 is a $14 \mathrm{bp}$ inverted repeat structure that contains the $10 \mathrm{bp}$ consensus sequence for species-specific uptake of DNA by gonococci. This sequence motif has been proposed to be part of a signal involved in transcriptional attenuation or termination (Goodman and Scocca, 1988). Using the initiation codon at nucleotide position 252, ORF1 would encode a putative protein of 558 amino acids with a molecular weight of 61759 .

In the course of determining the nucleotide sequence of this region, ORF2 was identified downstream of, and in the opposite orientation relative to, ORF1 (see Fig. 9 later). The nucleotide sequence of this region is shown in Fig. 2. This ORF has an in-frame ATG start codon at nucleotide position 114 which is preceded by a putative ribosome-binding site (AGGA) 6 bp upstream, an alternate in-frame initiation codon for valine at nucleotide position 147 and ends at position 972 . The predicted primary translation product of the ORF beginning at position 114 would encode a 286-amino-acid polypeptide with a molecular weight of 31315 .

The DNA sequence of the region of locus 2 clones that includes the pilB homologous sequences is shown in Fig. 3. As noted for locus 1, contained within the sequence is a large open reading frame, ORF3, which encompasses a region of pilB homology. This ORF has three potential in-frame translational initiation codons at nucleotide positions 543, 567 (GTG) and 588, and ends at position 1665. The first ATG is preceded by a potential ribosome-binding site (GAGG) 6 bp upstream, and the second ATG also has a possible ribosome-binding site (GGAG) 7 bp upstream. Initiation at the first ATG would result in the expression of a 374-amino-acid polypeptide with a molecular weight of 41095 . Another segment of the locus 2 DNA, mapping immediately upstream of ORF3, was found to be significantly homologous to the pilB gene sequences. This DNA homology was contained within an ORF, termed ORF4, that is read off the opposite strand with respect to ORF3. It has an in-frame ATG codon at nucleotide position 685 , overlapping the $5^{\prime}$ end of ORF3, 


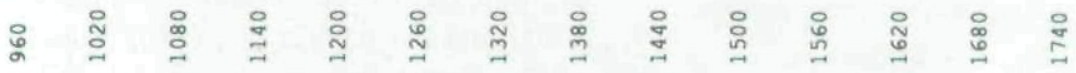
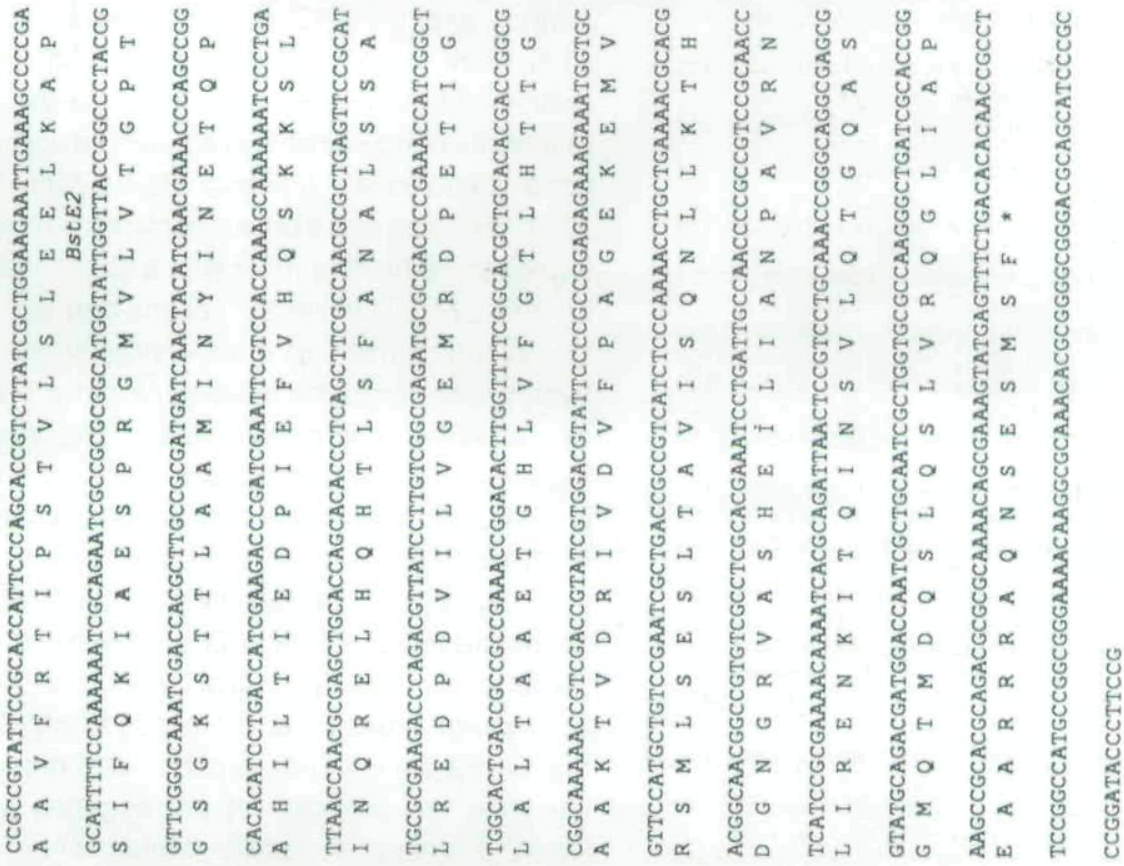

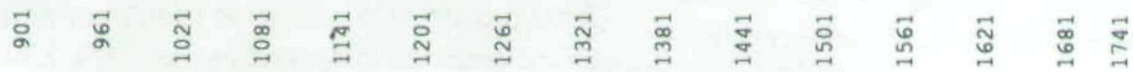

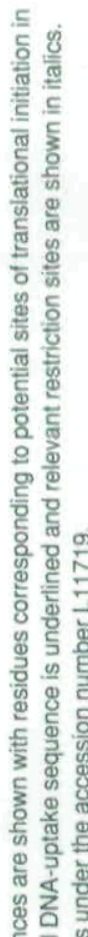

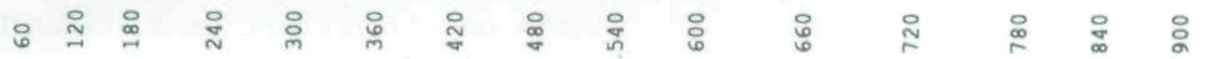

बํำ

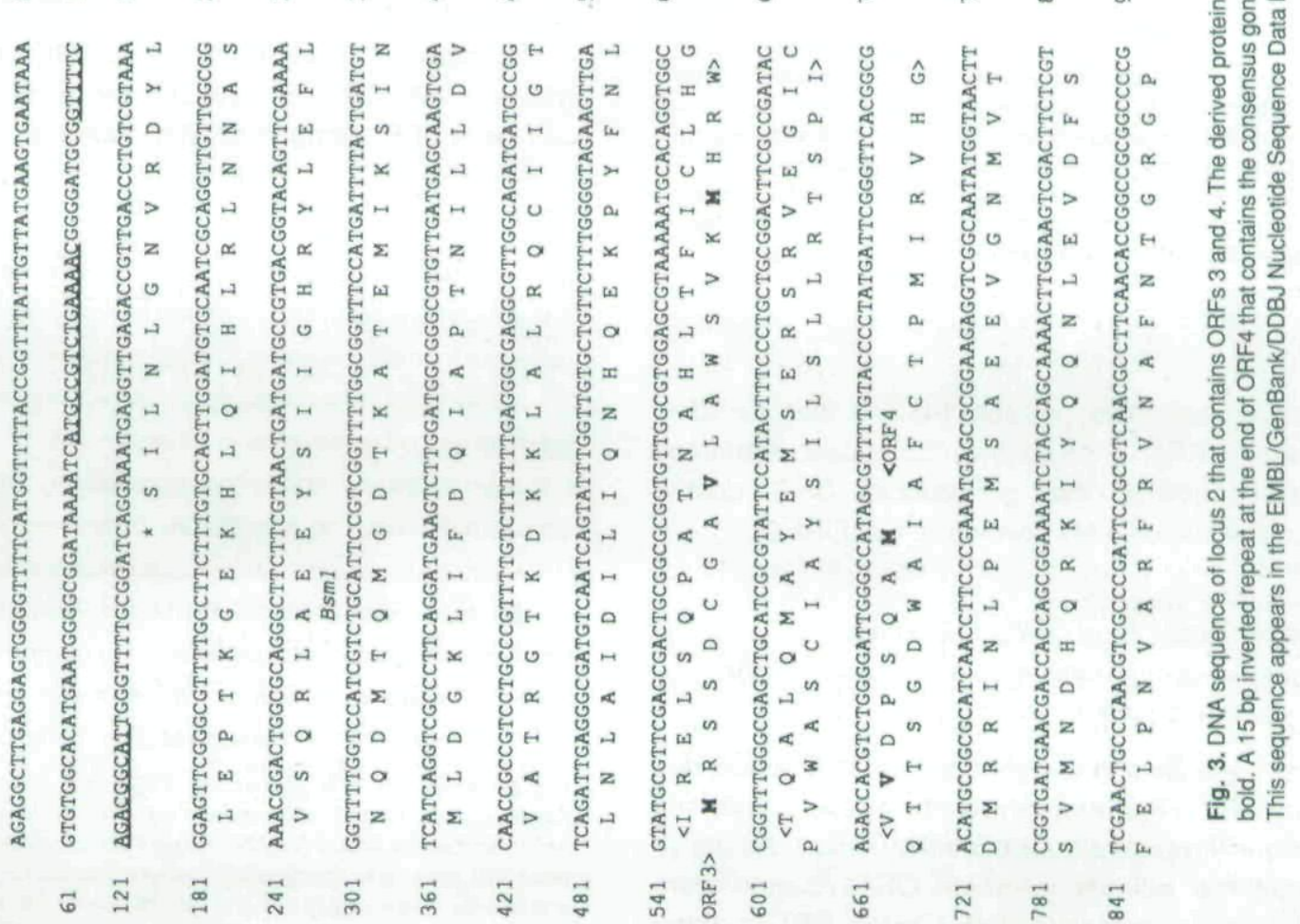


1 MSVGLLRILVQNQVVTVEQAEHYYNESQAGK. EVLPMLESDGVI 43 L I | | | |

1 MNDSIQLS, GLSRQLVOANLLDEKTALQAQTQAQRNKLSLVTHLVQNKLV 49

44 SPKSLAALIARVESYSILDLRHYPRHRVLMGVLTEEQMVEFHCVPVFRRG 93

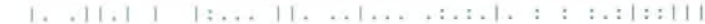

50 SGLALAELSAEQFGIAYCDLNSLDRESEPRDAISEKLVROHRVIPLWRRG 99

94 DKVFFAVSDPTQMPQIOKTVSAAGIAVELVIVEDDQLAGLLDWVGSRSTS 143

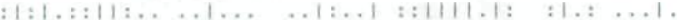

100 NKLEVGISDAANHQAINDVQESTGLTTEAILVEDDKLGLAIDKLFENATD 149

144 LLQELGEGQEEE . . . . ESHTLYIDNEEAEDGPVPRF IHKTLSDALRSG 187

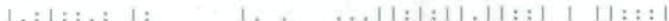

150 GLAGLDDVDLEGLDVGVKETSGQEDTGAEADDAPVVRFVNKMLLDAIKGG 199

48 ASDIHFEFYEHNAR IRFRVDGQLREVVQPP IAVRGQLASRIKVMSRLDIS 237

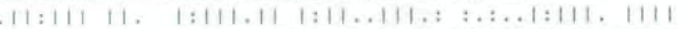

200 SSDLHFEPYEKIYRVRFRTDGMLHEVAKPPIQLASRISARLKVMAGLDIS 249

238 EKRIPQDGRMQLTFQKGGKPVDFRVSTLPTLFGEKVVMRILNSDAASLNI 287

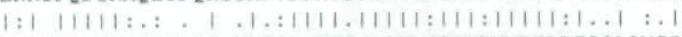

250 ERRKPQDGRIKMRVSK, TKSIDFRVNTLPTLWGEKIVMRILDSSSAQMGI 298

288 DQLGFEPFQKKLLLEAIHRPYGMVLVTGPTGSGKTVS LYTCLNILNTESV 337 $1.11: 1.11,1.1,1: \ldots 1|11:| 1111111111111111.111111 \ldots$ :

299 DALGYEEDQKELYLAALKQPQGMILVTGPTGSGKTVSYYTGLNILNTTDI 348 A

338 NIATAEDPAEINLPGINQVNVNDKQGLTEAAALKSFLRQDPDIIMVGEIR 387 $11.11111 .1111 .11111111 .: 11: .1 \ldots 11: .1111111: 1111111$

349 NISTAEDPVEINLEGINQVNVNPRQGMDE SQALRAFLRODPLVIMVGEIR 398 B

388 DLETADIAIKAAQTGHMVFSTLHTNNAPATLSRMLNMGVAPFNIASSVSL 437 $11111: 111111111111: 111111,1:, 11.1: 11111:: 11: 1.11,1$

399 DLETAEIAIKAAQTGHMVMSTLHTNSAAETLTRLLNMGVPAFNLATSVNL 448

438 IMAQRLLRRLCSSCKQEVERPSASALKEVGFTDEDLAKDWKLYGAVGCDR 487

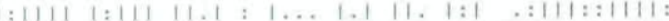

449 ITAORLARKLCSHCKKEHDVPKETLLHE. GFP, EELIGTFKLYSPVGCDH 496

488 CRGQGYKGRAGVYEVMP I SEEMQRVIMNNGTEVGILDVAYKEGMVDLRRA 537

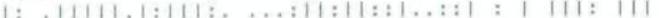

497 CK. NGYKGRVGIYEVVKNTPALQRIIMEEGNSIEIAEQARKEGENDLRTS 545

538 GILKIMQGITSLEEVTANTND* 558

$1: 14111414111,4.1$

546 GLLKAMQGITSLEEVNRVTKD* 567

Fig. 4. Comparison of $N$. gonorrhoeae PilF and $P$. aeruginosa PilB. The GAP Program of the UWGCG package was used to compare the deduced amino acid sequences of $N$. gonorrhoeae PilF (upper line) and $P$. aeruginosa PilB (lower line). Identical residues are indicated by vertical lines and related residues by colons and periods. The boxed residues represent regions homologous to the type $\mathrm{A}$ and $\mathrm{B}$ domains proposed to be part of a nucleoside triphosphate binding fold.

and ends at nucleotide position 146. As was found in the case of ORF1, a $15 \mathrm{bp}$ inverted repeat sequence structure containing the gonococcal DNA uptake sequence lies immediately downstream of ORF4.

\section{Deduced polypeptides of ORFs 1,2, and 3 are} homologues of components required for type IV pilus assembly and two-step protein export

A database search with the gonococcal DNA sequences using the FASTA Program revealed notable similarities with previously reported nucleotide sequences. As anticipated from the manner in which ORF1 clones were selected, highly significant matches to this ORF included the $P$. aerginosa pilB gene itself and, in decreasing order of relatedness, the pulE gene of $K$. oxytoca (Pugsley et al., 1990), the xpsE gene of $X$. campestris (Dums et al., 1991 ) and the comG1 gene of B. subtilis (Albano et al., 1989). Direct comparison of the ORF1-derived polypeptide and the PilB protein showed that they shared $51 \%$ identity and $71 \%$ similarity (Fig. 4 ). The highest degrees of identity were localized to the central region that contained two conserved domains proposed to comprise a nucleoside triphosphate binding fold (Walker et al., 1982). The first domain contains a type A nucleoside triphosphate binding motif with a consensus sequence of GXXXXGK(S/T) while the second domain consists of the less highly conserved motif characterized by a string of hydrophobic residues followed within a few amino acids by negatively charged residues. The overall structural features of these two polypeptides including hydropathy profiles, isoelectric points and molecular weights were virtually identical.

Highly significant matches to the ORF2 nucleotide sequence included the pilD/xcpA gene of $P$. aeruginosa (Nunn et al., 1990; Bally et al., 1991) and the pulO gene of K. oxytoca (Pugsley and Reyss, 1990). Comparison of the ORF2-derived polypeptide with other polypeptides identified the products of these genes as well as the ComC protein of B. subtilis (Mohan et al., 1989) and the TcpJ protein of $V$. cholerae (Kaufman et al., 1991). The ORF2-encoded polypeptide has $48 \%$ identity and $65 \%$ similarity to the PilD/XcpA protein of $P$. aeruginosa and the regions of relatedness are distributed throughout the proteins (Fig. 5).

In contrast to the results found for ORF1, the significant matches with ORF3 in ranked order of identity were the pilT gene of $P$. aeruginosa (Whitchurch et al., 1991), the

\footnotetext{
MSDLSVLSPFAVPLAAV. LGLLVGSFLNVVIYRVPVMMERGWTVFAKE 47 $: 1.01: 1,1.1: 111111111.11: .1: 1 \mid 1111,1 \ldots$ |: 1 MPLLDYLASHPLAFVLCAILLGLLVGSFLAVVVHRLPKMMERNWKAEARE 50 48 HLNLPLTDDESRTFNLMKPDSC CPKCRVP IRAWQNIPIVSYLLLRGKCAS 97

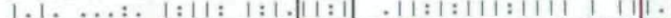
51 ALGLEPEPKQA. TYNLVLPNSA CPRCGHEIRPWENIPLVSYLALGGLSS 99

98 CDTKISIRYPLIELLTGVLEGLVAWQYGWSWITLGGLILTAFLISLTFID 147

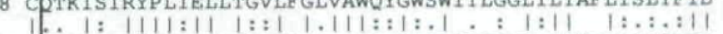
00 CKAAIGKRYPLVELATALLSGYVAWHFGFTWQAGAMLLLTWGLLAMSLID 149

148 ADTQYLPDSMTLPLIWLGLIFNLDGGEVPLQSAVLGAVAGYSSLWLLCAV 197

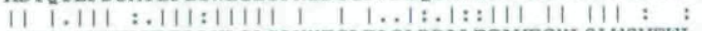
150 ADHQLLPDVLVLPLLWLGLIANHF GLFASLDDALFGAVFGYLSLWSVEWL 199

198 YKLLTGKTGMGNGDFKLIAALGAWLGISALPVLIFVSSLIGLVAATVMRR 247

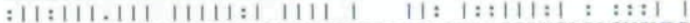
00 EKLVTGKEGMGYGDFKLLAMLGAWGGWOILPLT ILLSSLVGAILGVIMLR 249

$248 \mathrm{RQ} \ldots$ GAAFLVGPALTVSGWIIFTANDSVWRAVNWWLTHPVR* 287 1.:: . | | |.:.111: : । : |. : : 250 LRNAESGTPIPEGPYLAIAGWIALLWGDQITRTYLOFAGEK* 290
}

Fig. 5. Comparison of $N$. gonorrhoeae PilD and $P$. aeruginosa PilD. The GAP Program of the UWGCG package was used to compare the deduced amino acid sequences of $N$. gonorrhoeae PilD (upper line) and $P$. aeruginosa PilD (lower line). Identical residues are indicated by vertical lines and related residues by colons and periods. Boxed residues contain dithiol motifs that are conserved in prepilin leader peptidase family members (Kaufman et al., 1991; Whitchurch et al., 1991). 
1 MRSSDCGAVLAWSVKMHRWPVWASCIAYSILSLLRTSPIQTTSGDWAIAF 50 I. I1 I: 1...1: 1 MDITELLAFSAKQGASDLHLSAG 23

51 CTPMIRVHGDMRRINLPEMSAEEVGNMVTSVMNDHQRKIYQQNLEVDFSE 100

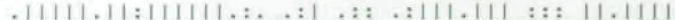
24 LPPMIRVDGDVRRINLPPLEHKOVHALIYDIMNDKQRKDEEEFLETDESF 73

101 ELPNVARERVNAFNTGRGPAAVFRTIPSTVLSLEELKAPSIFOKIAESPR 150 $1: 1.1111111111,11:: 11111111,11,: 111, \ldots: 1,::: 111$

74 EVPGVARERVNAFNONRGAGAVERTIPSKVLTMEELGMGEVEKRVSDVPR 123

151 GMVVTGPTGSGKSTT AAMINYINETQPAHILTIEDPIEFVHQSKKSLI 200 1:111111111111111111::1:1:1. 1111111111111:111:1:

124 GLVEVTGPTGSGKSTTHAMLDYLNNTKYHHILTIEDP IEFVHESKKCLV 173 A

NQRELHQHTLSFANALSSALREDP VILVGEMRDPETIGLALTAAETGHL 250 $111: 1 \ldots 11: 1 \ldots: 11.11111111: 11111111$ ||1 11111111111

174 NQREVHRDTLGF SEALRSALREDP I ILVGEMRDLETIRLALTAAETGHL 223

251 VEGTLHTTGAAKTVDRIVDVFPAGEKEMVRSMLSESLTAVISONLLKTHD 300 11111111:1111:11:111111:11, 1111111111:1111,1:1.

224 VFGTLHTTSAAKTIDRVVDVFPAEEKAMVRSMLSESLQSVISQTLIKKIG 273

301 GNGRVASHEILIANPAVRNLIRENKITQINSVLQTGQASGMQTMDQSLQS 350

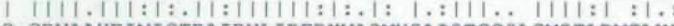

274 G.GRVAAHEIMIGTPAIRNLIREDKVAQMYSAIQTGGSLGMOTLDMCLKG 322

351 LVRQGLIAPEAARRRAQNSESMSF * 375

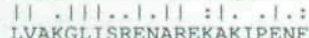

Fig. 6. Comparison of $N$. gonorrhoeae PilT and P. aeruginosa PilT. The GAP Program of the UWGCG package was used to compare the deduced amino acid sequences of $N$. gonorrhoeae PilT (upper line) and $P$. aeruginosa PilT (lower line). Identical residues are indicated by vertical lines and related residues by colons and periods. The boxed residues represent regions homologous to the type $\mathrm{A}$ and $\mathrm{B}$ domains proposed to be part of a nucleoside triphosphate binding fold.

$x p s E$ gene of $X$. campestris (Dums et al., 1991), the pulE gene of $K$. oxytoca and the pilB gene of $P$. aeruginosa. A comparison of the polypeptide encoded by ORF3 with the PilT protein demonstrated that they shared $63 \%$ amino acid identity and $77 \%$ similarity (Fig. 6). As noted above for the PilB protein and ORF1-derived polypeptide, the regions of highest identity encompassed the type $A$ and $B$ consensus nucleoside triphosphate binding domains. The PilT protein and the ORF3-derived polypeptide also displayed highly related structural characteristics incuding their size, overall hydrophilicity and charge. The deduced polypeptide of ORF4 was also structurally related to the derived polypeptide of ORF3 $(31 \%$ identity over 154 amino acid residues) and, to a lesser degree, the products of the pilB/pilT/pulE gene family (data not shown). Computer-assisted searches using the other reading frames found in the nucleotide sequences shown in Fig. 1,2 , and 3 , and that of their predicted polypeptides, failed to reveal any significant matches with sequences in the database.

\section{Identification of expressed polypeptides corresponding to} ORFs 1,2 , and 3

We next sought to identify polypeptides expressed by the cloned DNAs that corresponded to the ORFs. Since no definitive information was available with regard to potential transcriptional promoters, restriction fragments chosen so as to contain principally the ORFs of interest were cloned in the proper orientation downstream of the lac promoter present in the pBluescript-II SK/KS vectors (see Fig. 9 later). As controls, translational frameshift mutations designed to disrupt the ORFs were engineered into each clone by filling in single-stranded ends generated by endonuclease digestion with Klenow polymerase followed by intramolecular ligation. Purified plasmid DNAs were used to prime an in vitro transcription-translation system to visualize the proteins they encoded. The translated products were labelled by incorporation of $\left[{ }^{35} \mathrm{~S}\right]-$ methionine and analysed by SDS-PAGE and autoradiography (Fig. 7).

The construct pORF1 produced two unique polypeptides of $M_{\mathrm{r}} 57 \mathrm{kDa}$ and $55 \mathrm{kDa}$ that were replaced by polypeptides of $M_{\mathrm{r}} 28 \mathrm{kDA}$ and $27 \mathrm{kDa}$ when the derivative construct pORF1 $1 \Delta$ with the frameshift mutation was examined (Fig. 7, lines 1 and 2). The source of the double banded migration pattern is unknown but seemingly identical behaviour has been documented for the ExeE protein which is required for aerolysin secretion by Aeromonas hydrophila and is a member of the same secretion component family as the ORF1-encoded polypeptide (Jiang and Howard, 1992). The authors of that work proposed that the two bands observed for ExeE reflected differential post-translational modification of a single protein species.

The construct pORF2 produced a $M_{\mathrm{r}} 25 \mathrm{kDa}$ protein while its derivative with a frameshift mutation produced a

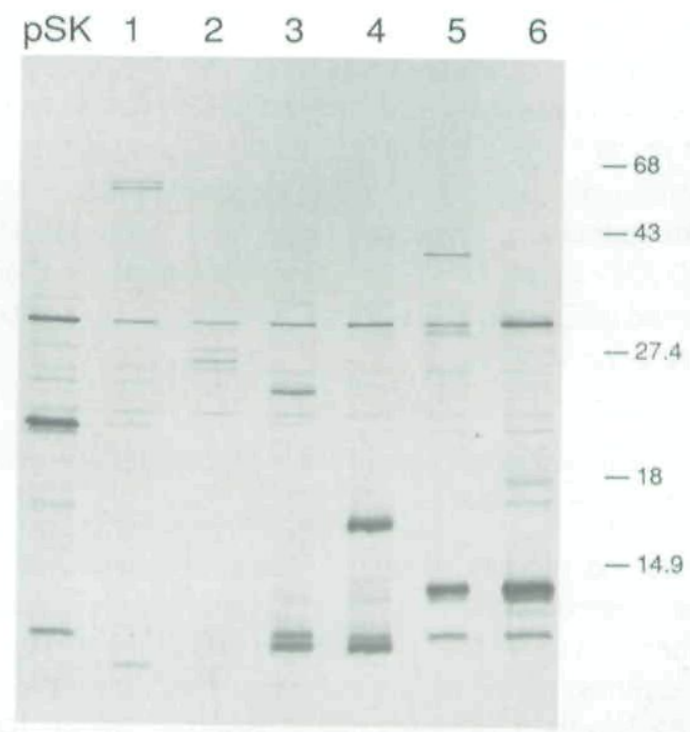

Fig. 7. Identification of proteins corresponding to ORFs 1,2 and 3 by in vitro transcription-translation reactions, SDS-PAGE and autoradiography. The $M_{r}$ values of protein size standards are shown in kDa on the right. Polypeptides encoded by the vector pBluescript II SK (pSK): pORF1 (lane 1); pORF1 $\Delta$ (lane 2); pORF2 (lane 3); pORF2 $\Delta$ (lane 4); pORF3 (lane 5) and pORF3 $\Delta$ (lane 6). See Fig. 9 for a description of plasmid constructs and predicted $M_{r}$ values deduced from the ORFs (numbering in Fig. 9 corresponds to lane numbers used here) 


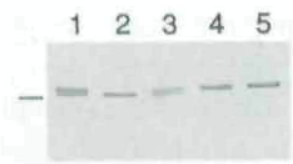

Fig. 8. Processing of gonococcal prepilin in E. coli strains expressing gonococcal PilD showing an immunoblot of whole-cell lysates derived from strains carrying pBluescript II SK and pVD302. $\mathrm{P}^{+-}$(expressing gonococcal prepilin), lane 1; pORF2 and pVD302P*+, lane 2; pORF2 $\Delta$ and

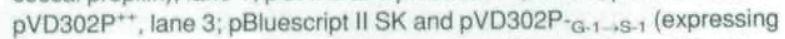
a mutant prepilin incapable of being processed by prepilin peptidase),

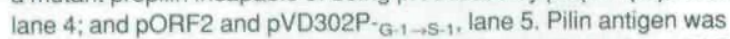
detected with the monoclonal antibody O2. The position of an $18 \mathrm{kDa}$ protein size standard is noted on the left.

$M_{r} 16.1 \mathrm{kDa}$ polypeptide (Fig. 7, lines 3 and 4). Although the sizes of the observed and predicted polypeptides for the frameshift mutant of ORF2 were in concordance, a discrepancy existed between the $31 \mathrm{kDa}$ predicted for the unaltered open reading frame and the smaller protein found. This may merely represent the peculiarities of this protein and of SDS-PAGE, which often fails to provide a consistent correlation between molecular weight and relative mobility. Precedence for this can be found in the results of studies of the PilD protein of $P$. aeruginosa with which the ORF2-encoded polypeptide shares strong homology. That protein has a predicted molecular weight of 31839 but also migrates with a $M_{r}$ of $25 \mathrm{kDa}$ (Nunn and Lory, 1991).

The construct pORF3 expressed a $M_{\mathrm{r}} 39 \mathrm{kDa}$ protein which was missing in its altered derivative pORF $3 \Delta$ where a $M_{r} 17.5 \mathrm{kDa}$ protein was found; these values are in good agreement with those predicted for the derived polypeptides of the wild-type and mutated ORF3. Based on these results and the extreme structural relatedness of these polypeptides with the homologues in $P$. aeruginosa, the corresponding gonococcal genes have been designated pilD (ORF2) and pilT (ORF3) while the gene for ORF1 is termed pilF (since the allele designation pilB has prior use in N. gonorrhoeae).

\section{Expression of gonococcal PilD is associated with prepilin processing activity}

Since the product of the $P$. aeruginosa pilD gene has been demonstrated to be a prepilin leader peptidase (Nunn and Lory, 1991), we sought to determine if the corresponding gonococcal gene product had a similar enzymatic activity. To address this, E. coli strainDH5 $\alpha \mathrm{F}^{\prime} \mathrm{IQ}$ harbouring pORF2 was transformed with compatible plasmids which carried genes encoding either a wild-type gonococcal prepilin or a mutant prepilin which had a serine residue at position -1 , rather than glycine. This amino acid substitution results in a protein that is incapable of being processed by prepilin peptidases (Koomey et al.,
1991). Controls included strains in which the wild-type PilD-expressing plasmid were replaced by either the cloning vector pBluescript II SK or pORF2A. Whole-cell lysates prepared from logrithmically growing cultures were subjected to SDS-PAGE and immunoblotting using the pilin-specific monoclonal antibody $\mathrm{O} 2$ (Fig. 8). E. coli strains express an endogenous processing activity for gonococcal prepilin related in its substrate specificity and activity to the family of prepilin leader peptidases which accounted for the appearance of two pilin species in this background (Koomey et al., 1991). Pilin expressed in presence of the gonococcal pilD gene product was detected as a single species with the same relative mobility as the faster migrating of the two forms found in its absence. This altered pilin processing was confirmed to be associated with PilD expression by virtue of the lack of modification found in the presence of the mutated pilD gene. In addition, PilD-related processing was not seen when the mutant prepilin incapable of being proteolytically processed by gonococcal prepilin peptidase was tested (Fig. 8, lines 4 and 5), providing further evidence that the activity associated with the PilD protein was characteristic of prepilin leader peptidase.

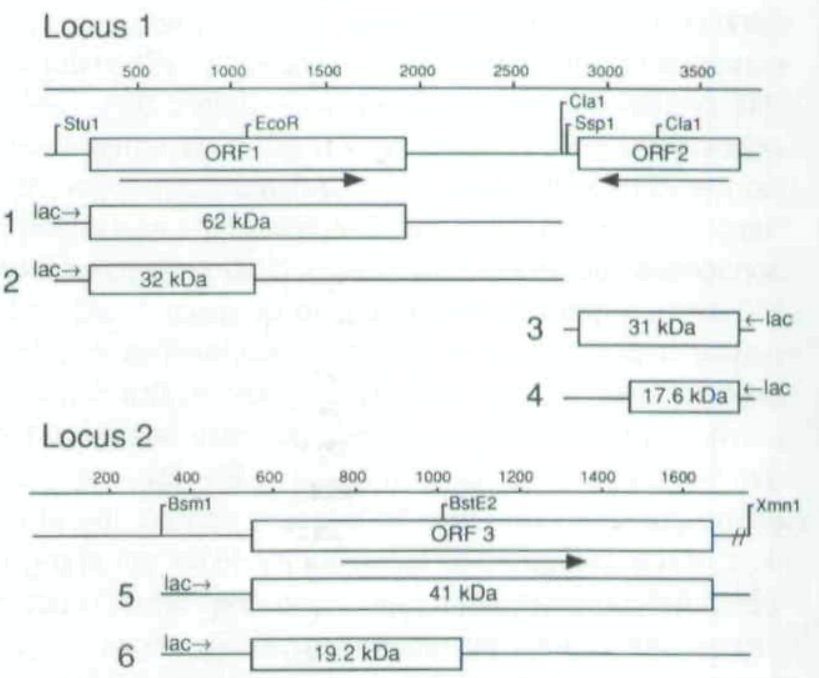

Fig. 9. Physical maps of locus 1 and 2 and locations of ORFs 1,2 and 3. Plasmids used to identify encoded polypeptides corresponding to ORFs were constructed as follows: 1, pORF1, an Stul-Clal fragment cloned into Smal-Clal-digested pBluescript II SK; 2, pORF1 1 , derived from pORF1 by filling in the $3^{\prime}$ recessed overhang generated by EcoRI digestion with Klenow polymerase; 3 , pORF2, a Bsth-Sspl fragment cloned into BamHI-Hincll digested pBluescript II SK, 4, pORF2A, derived from pORF2 by filling in the $3^{\prime}$ recessed overhang generated by Clal digestion with Klenow polymerase; 5 , pORF3, a Bsml-Xmnl fragment cloned into Smal digested pBluescript II KS; 6 , pORF3 3 , derived from pORF3 by filling in the $3^{\prime}$ recessed overhang generated by BstEll digestion with Klenow polymerase. Molecular weights shown are those of polypeptides predicted for the wild-type and mutated ORFs. Note that the numbering used here corresponds to the lanes shown in the autoradiogram in Fig.7 to facilitate comparison of the predicted and observed polypeptides. 


\section{Discussion}

We have described the isolation and characterization of three genes in $N$. gonorrhoeae encoding proteins with substantial similarities to known components of a specialised pathway of protein export widely distributed among eubacterial species. Two of the genes were directly identified by virtue of their hybridization with a DNA probe derived from the pilB gene of $P$. aeruginosa under conditions of reduced stringency. The success of this approach supports previous proposals that DNA homologies detected across species boundaries using secretion-component gene probes reflect the presence of analogous gene families (deGroot et al., 1991; Dupuy et al., 1992).

Proteins sharing significant structural relatedness to the gonococcal PilF protein have been found in virtually all of the two-step protein export pathways that have been genetically dissected. The common features of proteins in this family include an overall hydrophilic character with a lack of obvious membrane-spanning regions or leader sequences as well as the presence of both a consensus nucleoside triphosphate binding domain and a secondary nucleoside binding-associated sequence (Ward et al., 1988; Albano et al., 1989; Dums et al., 1991; He et al., 1991; Whitchurch et al., 1991; Bally et al., 1992; Jiang and Howard, 1992; Possot et al., 1992; Sandkvist et al., 1993). Although the presence of the conserved binding sites has led to proposals that they may couple ATP hydrolysis with an energy-dependent transport process, a defined role for these components is lacking.

The gonococcal PilD protein likewise shows a high degree of similarity to the products of a gene family widely represented in prokaryotic protein secretion systems. Included in this family are the pilD/ $x c p A$ gene of $P$. aeruginosa, the pulO gene of $K$. oxytoca, the com $C$ gene of $B$. subtilis and the tcpJ gene of $V$. cholerae. The products of these genes are $20-30 \mathrm{kDa}$ proteins containing multiple hydrophobic domains with membrane-spanning potential and it appears that they are localized to the cytoplasmic membrane (Pugsley and Reyss, 1990; Bally et al., 1991; Nunn and Lory, 1991). One particularly unique character of these proteins is the presence of two copies of the dithiol motif, CXXC (Fig. 5), with conserved spacing relative to one another (Kaufman et al., 1991; Whitchurch et al., 1991). The expression of each of these proteins is associated with prepilin peptidase activity. Moreover, specific endopeptidase activity with the purified gene product has been directly demonstrated for the PiID protein of $P$. aeruginosa (Nunn and Lory, 1991). Our studies show that the gonococcal pilD gene product is also associated with gonococcal prepilin processing activity but we cannot formally rule out the possibility that the gonococcal protein activates or potentiates the endogenous pepti- dase activity present in E. coli. Based on the extreme degree of shared amino acid identity between the gonococcal and pseudomonas PilD proteins, we feel that this possibility is unlikely and that gonococcal PilD protein is a prepilin leader peptidase.

The gonococcal pilT gene is the first homologue of the pilT gene of $P$. aeruginosa to be characterized. The latter gene was identified by virtue of its ability to phenotypically complement a pseudomonas pilus mutant which retained piliation but was altered in the pilus-associated properties of twitching motility, colony morphology and susceptibility to bacteriophage infection (Bradley, 1980; Whitchurch et al., 1991). The basis for the association between these phenotypes, pili and PilT expression in P. aeruginosa are not known. Gonococci also share the properties of pilusdependent twitching motility and colony morphology (Henrichsen, 1975). Both PilT proteins have an overall hydrophilic character and are likely to be cytoplasmically located. The products of these genes also contain the two domains characteristic of the nucleoside triphosphatebinding proteins found in the other protein family involved in protein export pathways but are less related to those other proteins than they are to one another. Computer analysis of the gonococcal pilT locus also revealed a second ORF, overlapping and divergently oriented relative to the pilT gene (ORF4) whose derived polypeptide shows $31 \%$ identity with the carboxy-terminal part of the gonococcal PilT protein. The possible significance of this observation awaits further study.

Other highly conserved genes and gene products in addition to those described here are required for assembly and secretion within the type IV pilus and protein export systems. These genes are often linked to those encoding the nucleoside triphosphate-binding proteins and prepilin peptidase components and are frequently arranged in a tandem array. Although the gonococcal pilF and pilD genes are configured in a convergent fashion, the linkage with other related genes appears to hold true in gonococci since a gene encoding a homologue of the PilC protein of $P$. aeruginosa (Nunn et al., 1990) and PulF protein of K. oxytoca (Pugsley et al., 1990) maps immediately upstream of the pilD gene (T. Tønjum, personal communication). Pulsed-field gel analysis has been used to identify the relative genomic positions of loci 1 and 2 in strain MS11 (J. A. Dempsey and J. Cannon, personal communication). Locus 1 maps to Nhel fragment I, a region of the genome that contains only one previously identified gene, that being the $r \mathrm{rnB}$ allele. Locus 2, containing the pilT gene, maps to the same Spel fragment which contains the pilC1 gene (Bihlmaier et al., 1991) whose product has been implicated in pilus assembly although the precise relative locations of these two genes are not yet established. Hence, the two loci are situated at least $100 \mathrm{~kb}$ apart from one another and both are remote 
from the pilin expression locus, pilE, where the pilus subunit encoding gene is found.

The gonococcal pilD and pilF genes and their corresponding proteins are most closely related to their counterparts in $P$. aeruginosa. This may be representative of constraints imposed by the requirements for the gene products to function in type IV pilus assembly, as opposed to the situation in other secretion systems which are not associated with those structures. Alternatively, $N$. gonorrhoeae may be more closely phylogenetically related to $P$. aeruginosa than to the other species with members of these gene families although this does not appear to be the case (Relman et al., 1992). Evidence for a common genetic origin and/or a limited degree of divergence is most compelling in the case of the pilT genes which are more related at the DNA level (69.4\% identity) than the other two gene pairs $(59.1 \%$ and $60.1 \%)$. The PilT proteins also share the highest level of amino acid identity $(63 \%)$ relative to the two other protein pairs $(48 \%$ and $56 \%$ ). Finally, the gonococcal PilT gene has a $\mathrm{G}+\mathrm{C}$ content of $58.3 \%$ which is closer in base composition to that found for pseudomonas genes (average 60-65\%) than for gonococcal genes (average 48-52\%) (Marmur et al., 1963).

We are currently characterizing gonococcal mutants that have defined lesions in each of the three genes described in these studies. While it is anticipated that these mutants will be altered in pilus expression, the possibility exists that the gene products may be involved in secretion of other proteins or membrane transport of other macromolecules, either alone or in concert with pilin transport and assembly. For example, expression of competence for transformation and DNA uptake are tightly coupled with pilus expression (Seifert et al., 1990; Zhang et al., 1992). Pilin, IgA1 protease (Pohlner et al., 1987), capsular polysaccharides and polyphosphate (Noegel and Gotschlich, 1983) are the only molecules currently known to be secreted by pathogenic Neisseria species. Therefore mutants altered in the expression of the secretion-component homologues we have characterized may be of use in identifying other molecules elaborated by gonococci and meningococci which influence their interaction with the human host.

\section{Experimental procedures}

\section{Bacterial strains, plasmids and bacteriophages}

N. gonorrhoeae strain MSO1-1X was propagated on clear solid medium at $36^{\circ} \mathrm{C}$ in $5 \% \mathrm{CO}_{2}$ or in that media lacking agar that had been preincubated overnight in $5 \% \mathrm{CO}_{2}$. E. coli strains $\mathrm{HB} 101\left(\mathrm{~F}^{-}, \mathrm{mcrB}, \mathrm{mrr}\right.$, hsdS20 $\left(\mathrm{r}_{\mathrm{B}}^{-}, \mathrm{m}_{\mathrm{B}}^{-}\right), \operatorname{rec} A 13$, supE44, ara14, galk2, lacY1, proA2, rpsL20, xyl15, leu, $m t / 11)$ and

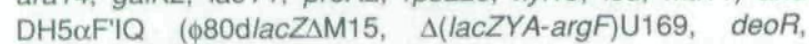
recA1, endA1, hsdR17, $\left(\mathrm{r}_{\mathrm{k}}^{-}, \mathrm{m}_{\mathrm{k}}^{+}\right) \sup E 44$, thi-1, gyrA96, relA1,
$\mathrm{F}^{\prime}$ pro $A B^{+}, \operatorname{lac}^{9} \mathrm{Z} \triangle \mathrm{M} 15 \mathrm{zzf}: \mathrm{Tn} 5$ ) were used in plasmid cloning experiments while strain KW251 ( $F$, supE44, galK2, galT22, metB1, hsdR2, mcrB1, argA81:Tn 10, recD1014) was used in the propagation of recombinant phage clones. The gonococcal genomic library was constructed using the phage $\lambda$ replacement vector EMBL-3 (Frischauf et al., 1983). Recombinant plasmids were made using the cloning vectors pACYC184, pREG153 (Koomey and Falkow, 1987), and pBluescript II SK/KS+ (Stratagene). E. coli strains were grown at $37^{\circ} \mathrm{C}$ in Luria-Bertani (LB) medium supplemented with appropriate antibiotics. The parental plasmid used in the sequencing of locus one, p12/7/1, was made by cloning a $3.5 \mathrm{~kb}$ BamHI-Smal fragment from $\lambda$ clone 10A into BamHI- and Smal-digested pBluescript II SK+. The complete pilF gene, which was not present in $\lambda$ clone $10 \mathrm{~A}$, was cloned as a Stul-Clal fragment from cosmid clone AH1. The plasmid p2A2, used for the DNA sequencing of locus 2 , was constructed by cloning an $11 \mathrm{~kb}$ Smal fragment from $\lambda$ clone $18 / 4$ into the Smal site of pBluescript II SK+. The gonococcal pilin genes derived from strains VD302 $\mathrm{P}^{++}$and VD302 $\mathrm{P}^{-}\left(\mathrm{G}_{-1} \rightarrow \mathrm{S}_{-1}\right)$ (Koomey et al., 1991) were cloned as $0.9 \mathrm{~kb}$ Hpal-Clal fragments using the plasmid vector pACYC184 which had been digested with ECORV and Clal. Construction of other plasmid clones is described in Fig. 9.

\section{DNA preparation and manipulation}

Gonococcal genomic DNA was prepared as previously detailed (Koomey et al., 1982). Isolation and purification of plasmid and phage DNAs were done using Qiagen columns according to the manufacturer's specifications. For the phage library, gonococcal DNA partially digested with SauBA endonuclease was fractionated by electrophoresis and fragments $12-18 \mathrm{~kb}$ in size were recovered by electroelution. This DNA was ligated to BamHI-digested EMBL-3 phage arms and encapsidated in phage particles using a Gigapack II Plus packaging extract (Stratagene). Other standard methods of DNA manipulation were performed as described (Sambrook et al., 1989). DNA sequencing of clones was performed by the dideoxy chain-termination method (Sanger et al., 1977) using a modified form of T7 DNA polymerase (Sequenase 2.0, United States Biochemical). The complete sequence of both strands was determined by subcloning, as well as by the use of appropriate deletion constructs and unique oligonucleotide primers.

\section{General protocols}

The $P$. aeruginosa pilB gene probe was the $1.5 \mathrm{~kb} P$ stl fragment of pDN19X1 (Nunn et al., 1990) which was labelled by a random priming reaction. Reduced stringency hybridizations of Southern blots and plaque lifts were done at $37^{\circ} \mathrm{C}$ using $5 \times$ SSC, $25 \%$ formamide and $200 \mu \mathrm{g} \mathrm{ml}^{-1}$ calf thymus DNA. Filter washes for the detection of the gonococcal gene homologues were done using $2 \times$ SSC, $0.1 \%$ SDS at $65^{\circ} \mathrm{C}$.

DNA and peptide sequence data were compiled and analysed by computer using both the MacVector 3.5 (International Biotechnologies Inc.) and University of Wisconsin Genetics Computer Group (UWGCG) software packages (Devereux et al., 1984). DNA homologies were found using the FASTA routine and protein homologies were identified using TFASTA. Pairwise alignments of proteins were performed using the GAP Program and default parameters. 
Polypeptides encoded by plasmids were identified by means of a coupled transcription-translation system. Reactions were carried out according to the supplier's recommendations (Promega) with $\left[{ }^{35} \mathrm{~S}\right]$-methionine (Amersham). Labelled polypeptides were separated by SDS-PAGE using $12 \%$ acrylamide gels, transferred to nitrocellulose filters by electroblotting and visualized by autoradiography.

Assays for gonococcal prepilin processing activity were performed as follows: $E$. coli strain $\mathrm{DH} 5 \alpha \mathrm{F}^{\prime} \mathrm{IQ}$ was transformed with plasmids carrying the gonococcal pilD gene and compatible plasmids expressing the gonococcal pilin genes from strain VD302 $\mathrm{P}^{++}$or VD302 $\mathrm{P}^{-}\left(\mathrm{G}_{-1} \rightarrow \mathrm{S}_{-1}\right)$ (Koomey et al., 1991). Cell suspensions made from overnight plate cultures were adjusted to an $\mathrm{OD}_{600}$ of 0.5 and diluted 1:10 in prewarmed LB broth. Following $4 \mathrm{~h}$ of growth, whole-cell lysates were prepared, fractionated by SDS-PAGE on $15 \%$ gels and the proteins transferred to nitrocellulose sheets. Filters were incubated with a 1:1000 dilution of the monoclonal antibody 02 specific for gonococcal pilin followed by exposure to an alkaline-phosphatase coupled goat anti-mouse immunoglobulin antibodies (Tago Inc.). Pilin antigen was detected by the use of a colorimetric alkaline phosphatase substrate. Details of the immunoblotting and antigen detection procedures have been published previously (Koomey et al., 1991).

\section{Acknowledgements}

We thank S. Lory and D. Nunn for the $P$. aeruginosa pilB-containing plasmid, pDN19X1. We also thank J. A. Dempsey and J. Cannon for providing the pulsed-field gel mapping data for loci 1 and 2, and V. DiRita and D. Friedman for helpful comments on the manuscript. N.H.A. was the recipient of travel stipend 9211-301 from the Swedish Natural Science Research Council (N.F.R.). This work was supported, in part, by Public Health Service Grant AI 27837 and NIH Grant MO1 RR 00042. M.K. is a Pew Scholar in the Biomedical Sciences.

\section{References}

Albano, M., Breitling, R., and Dubnau, D.A. (1989) Nucleotide sequence and genetic organization of the Bacillus subtilis comG operon. J Bacteriol 171: 5386-5404.

Bally, M., Ball, G., Badere, A., and Lazdunski, A. (1991) Protein secretion in Pseudomonas areuginosa: the $x с p A$ gene encodes an integral membrane protein homologous to Klebsiella pneumonia secretion function PulO. J Bacteriol 173: 479-486.

Bally, M., Filloux, A., Akrim, M., Ball, G., Lazdunski, A., and Tommassen, J. (1992) Protein secretion in Pseudomonas aeruginosa: characterization of seven $x c p$ genes and processing of secretory apparatus components by prepilin peptidase. Mol Microbiol 6: 1121-1131.

Bihlmaier, A., Römling, U., Meyer, T., Tümmler, B., and Gibbs, C. (1991) Physical and genetic map of the Neisseria gonorrhoeae strain MS11-N198 chromosome. Mol Microbiol 5: 2529-2539.

Bradley, D.E. (1980) A function of Pseudomonas aeruginosa PAO polar pili: twitching motility. Can J Microbiol 26: 146-154.

deGroot, A., Filloux, A., and Tommassen, J. (1991) Conservation of $x c p$ genes, involved in the two-step protein secretion process, in different Pseudomonas species and other gramnegative bacteria. Mol Gen Genet 229: 278-284.

Devereux, J., Haeberli, P., and Smithies, O. (1984) A comprehensive set of sequence analysis programs for the VAX. Nucl Acids Res 12: 387-395.

Dums, F., Dow, J., and Daniels, M. (1991) Structural characterization of protein secretion genes of the bacterial phytopathogen Xanthomonas campestris pathovar campestris: relatedness to secretion systems of other gram-negative bacteria. Mol Gen Genet 229: 357-364.

Dupuy, B., Taha, M.-K., Possot, O., Marchal, C., and Pugsley, A. (1992) PulO, a component of the pullulanase secretion pathway of Klebsiella oxytoca, correctly and efficiently processes gonococcal type IV prepilin in Escherichia coli. Mol Microbiol 6: 1887-1894.

Elleman, T.C., and Hoyne, P.A. (1984) Nucleotide sequence of the gene encoding pilin of Bacteroides nodosus, the causal organism of ovine footrot. J Bacteriol 160: 1184-1187.

Frischauf, A.M., Lehrach, H., Poustka, A., and Murray, N. (1983) Lambda replacement vectors carrying polylinker sequences. J Mol Biol 170: 827-842.

Giron, J.A., Ho, A.S.Y., and Schoolnik, G.K. (1991) An inducible bundle-forming pilus of enteropathogenic Escherichia coli. Science 254: 710-713.

Goodman, S., and Scocca, J. (1988) Identification and arrangement of the DNA sequence recognized in specific transformation of Neisseria gonorrhoeae. Proc Natl Acad Sci. USA 85: 6982-6986.

He, S.Y., Lindeberg, M., Chatterjee, A.K., and Collmer, A. (1991) Cloned Erwinia chrysanthemi out genes enable Escherichia coli to selectively secrete a diverse family of heterologous proteins into its milieu. Proc Natl Acad Sci USA 88: 1079-1083.

Heckels, J.E. (1989) Structure and function of pili of pathogenic Neisseria species. Clin Microbiol Rev 2: S66-S73.

Henrichsen, J. (1975) The occurrence of twitching motility among gram-negative bacteria. Acta Pathol Microbiol Scand Sect B 83: 171-178.

Hultgren, S., and Normark, S. (1991) Biogenesis of the bacterial pilus. Curr Opin Gen Develop 1: 313-318.

Jiang, B., and Howard, S.P. (1992) The Aeromonas hydrophila exeE gene, required both for protein secretion and normal outer membrane biogenesis, is a member of a general secretion pathway. Mol Microbiol 6: 1351-1361.

Jonsson, A.-B., Nyberg, G., and Normark, S. (1991) Phase variation of gonococcal pili by frameshift mutation in pilC, a novel gene for pilus assembly. EMBO J 10: 477-488.

Kaufman, M.R., Seyer, J.M., and Taylor, R.K. (1991) Processing of TCP pilin by TcpJ typifies a common step intrinsic to a newly recognized pathway of extracellular protein secretion by gram-negative bacteria. Genes Dev 5: 1834-1846.

Koomey, J.M., and Falkow, S. (1987) Cloning of the recA gene of Neisseria gonorrhoeae and construction of gonococcal RecA mutants. J Bacteriol 169: 790-795.

Koomey, J.M., Gill, R.E., and Falkow, S. (1982) Genetic and biochemical analysis of gonococcal $\lg A 1$ protease: cloning in Escherichia coli and construction of mutants of gonococci that fail to produce the activity. Proc Natl Acad Sci U S A 79: 7881-7885.

Koomey, M., Gotschlich, E.C., Robbins, K., Bergstrom, S., and Swanson, J. (1987) Effects of recA mutations on pilus antigenic variation and phase transitions in Neisseria gonorrhoeae. Genetics 117: 391-398.

Koomey, M., Bergstrom, S., Blake, M., and Swanson, J. (1991) Pilin expression and processing in pilus mutants of Neisseria 
gonorrhoeae: critical role of $\mathrm{Gly}_{-1}$ in assembly. Mol Microbiol 5: 279-287.

Lory, S. (1992) Determinants of extracellular protein secretion in gram-negative bacteria. J Bacteriol 174: 3423-3428.

Marmur, J., Falkow, S., and Mandel, M. (1963) New approaches to bacterial taxonomy. Annu Rev Microbiol 17: 329-372.

Marrs, C.F., Schoolnik, G., Koomey, J.M., Hardy, J., Rothbard, J., and Falkow, S. (1985) Cloning and sequencing of a Moraxella bovis pilin gene. J Bacteriol 163: 132-139.

Mohan, S., Aghion, J., N, G., and Dubnau, D. (1989) Molecular cloning and characterization of comC, a late competence gene of Bacillus subtilis. J Bacteriol 171: 6043-6051.

Noegel, A., and Gotschlich, E.C. (1983) Isolation of a high molecular weight polyphosphate from Neisseria gonorrhoeae. J Exp Med 157: 2049-2060.

Nunn, D.N., and Lory, S. (1991) The product of the Pseudomonas aeruginosa gene pilD is a prepilin leader peptidase. Proc Natl Acad Sci USA 88: 3281-3285.

Nunn, D., Bergman, S., and Lory, S. (1990) Products of three accessory genes, pilB, pilC and pilD, are required for biogenesis of Pseudomonas aeruginosa pili. J Bacteriol 172: 2911-2919.

Pohlner, J., Halter, R., Beyereuther, K., and Meyer, T. (1987) Gene structure and extracellular secretion of Neisseria gonorrhoeae IgA protease. Nature 325: 458-462.

Possot, O., d'Enfert, C., Reyss, I., and Pugsley, A.P. (1992) Pullulanase secretion in Escherichia coli $\mathrm{K}-12$ requires a cytoplasmic protein and a putative polytopic cytoplasmic membrane protein. Mol Microbiol 6: 95-105.

Potts, W.J., and Saunders, J.R. (1988) Nucleotide sequence of the structural gene for class I pilin from Neisseria meningitidis: homologies with the pilE locus of Neisseria gonorrhoeae. Mol Microbiol 2: 647-653.

Pugsley, A. (1992) Superfamilies of bacteria transport systems with nucleotide binding components? In Prokaryotic Structure and Function: A New Perspective. Society for General Microbiology Symposium 47. Mohan, M., Dow, C., and Cole, J. (eds). Cambridge: Cambridge University Press, pp. 223-248.

Pugsley, A.P., and Reyss, I. (1990) Five genes at the 3' end of the Klebsiella pneumoniae pulC operon are required for pullulanase secretion. Mol Microbio/ 4: 365-379.

Pugsley, A.P., d'Enfert, C., Reyss, I., and Kornacker, M.G. (1990) Genetics of extracellular protein secretion by gramnegative bacteria. Annu Rev Genet 24: 67-90.

Relman, D., Lepp, P., Sadler, K., and Schmidt, T. (1992) Phylogenetic relationships among the agent of bacillary angiomatosis, Bartonella bacilliformis, and other alpha-proteobacteria. Mol Microbiol 6: 1801-1807.

Sambrook, J., Fritsch, E.J., and Maniatis, T. (1989) Molecular Cloning. A Laboratory Manual. Cold Spring Harbor, New York: Cold Spring Harbor Laboratory Press.

Sandkvist, M., Morales, V., and Bagdasarian, M. (1993) A solu- ble protein required for secretion of cholera toxin through the outer membrane of Vibrio cholerae. Gene 123: 81-86.

Sanger, F., Nicklen, S., and Coulson, A.R. (1977) DNA sequencing with chain-terminating inhibitors. Proc Natl Acad Sci USA 74: 5463-5467.

Seifert, H.S., Ajioka, R.S., Paruchuri, D., Heffron, F., and So, M. (1990) Shuttle mutagenesis of Neisseria gonorrhoeae: pilin null mutations lower DNA transformation competence. $J$ Bacteriol 172: 40-46.

Shaw, C.E., and Taylor, R.K. (1990) Vibrio cholerae 0395 tcpA pilin gene sequence and comparison of the predicted protein structural features to those of type IV pilins. Infect Immun 58: 3042-3049.

Strom, M.S., and Lory, S. (1986) Cloning and expression of the pilin gene of Pseudomonas aeruginosa PAK in Escherichia coli. J Bacteriol 165: 367-372.

Strom, M.S., Nunn, D., and Lory, S. (1991) Multiple roles of the pilus biogenesis protein pilD: involvement of pilD in excretion of enzymes from Pseudomonas aeruginosa. J Bacteriol 173: 1175-1180.

Swanson, J., and Koomey, J.M. (1989) Mechanisms for variation of pili and outer membrane protein II in Neisseria gonorrhoeae. In Mobile DNA. Berg, D., and Howe, M. (eds), Washington, D.C.: ASM, pp. 743-761.

Taha, M.K., So, M., Seifert, H.S., Billyard, E., and Marchal, C. (1988) Pilin expression in Neisseria gonorrhoeae is under both positive and negative transcriptional control. EMBO J7: 4367-4378.

Taylor, R., Shaw, C., Peterson, K., Spears, P., and Mekalanos, J. (1988) Safe, live Vibrio cholerae vaccines? Vaccine 6: $151-154$

Tønjum, T., Marrs, C., Rozsa, F., and Bøvre, K. (1991) The type IV pilin of Moraxella nonliquefaciens exhibits unique similarities with pilins of Neisseria gonorrhoeae and Bacteroides nodosus. J Gen Microbiol 137: 2483-2490.

Walker, J.E., Saraste, M., Runswick, M.J., and Gay, N.J. (1982) Distantly related sequences in the $a$ and $b$ subunits of ATP synthase, myosin, kinases and other ATP-requiring enzymes and a common nucleotide binding fold. EMBO J1: 945-951.

Ward, J., Akiyoshi, D., Regier, D., Datta, A., Gordon, M., and Nester, E. (1988) Characterization of the virB operon from an Agrobacterium tumefaciens Ti plasmid. J Biol Chem 263: 5804-5814.

Whitchurch, C.B., Hobbs, M., Livingston, S.P., Krishnapillai, V., and Mattick, J.S. (1991) Characterisation of a Pseudomonas aeruginosa twitching motility gene and evidence for a specialised protein export system widespread in eubacteria. Gene 101: 33-44.

Zhang, Q.Y., DeRyckere, D., Lauer, P., and Koomey, M. (1992) Gene conversion in Neisseria gonorrhoeae: evidence for its role in pilus antigenic variation. Proc Natl Acad Sci USA 89: 5366-5370. 
Copyright of Molecular Microbiology is the property of Blackwell Publishing Limited and its content may not be copied or emailed to multiple sites or posted to a listserv without the copyright holder's express written permission. However, users may print, download, or email articles for individual use. 